\title{
CIVIL PROCEDURE AND PRACTICE: RECENT DEVELOPMENTS
}

GLEN H. POELMAN AND ALAN S. RUDAKOFF'

\section{TABLE OF CONTENTS}

I. INTRODUCTION $\ldots \ldots \ldots \ldots \ldots \ldots \ldots \ldots \ldots \ldots, 672$

II. DISCOVERY: EXAMINATION OF WITNESSES $\ldots \ldots \ldots 672$

III. DISCOVERY: DOCUMENTS $\ldots \ldots \ldots \ldots \ldots \ldots \ldots \ldots 676$

IV. COMPROMISE PROCEDURES $\ldots \ldots \ldots \ldots \ldots \ldots \ldots \ldots, 680$

V. ISSUANCE AND AMENDMENT OF PLEADINGS

AFTER TIME DEADLINES $\ldots \ldots \ldots \ldots \ldots \ldots \ldots \ldots \ldots 682$

VI. SECURITY FOR COSTS $\ldots \ldots \ldots \ldots \ldots \ldots \ldots \ldots \ldots \ldots, 686$

VII. INDEPENDENT MEDICAL EXAMINATION ........ 687

\section{INTRODUCTION}

There have recently been interesting and significant developments in a number of areas of civil practice. These developments are contained in the judgments of Alberta courts at various levels. The bar and academics are particularly fortunate in having many of the important areas again made so accessible in the recent publication of Stevenson and Côté's Civil Procedure Guide ${ }^{2}$.

It has, however, seemed useful to review briefly recent "highlights" in the area of civil procedure and practice. The decisions reviewed are, of necessity, somewhat selective, but an attempt has been made to address those which have the greatest significance for the conduct of a civil litigation practice and for the study of civil procedure.

\section{DISCOVERY: EXAMINATION OF WITNESSES}

There have been a number of decisions from the Court of Queen's Bench and the Court of Appeal dealing with the scope of examinations for discovery and the propriety of certain types of questions.

For years, many counsel have asked the question, with regard to particular allegations in pleadings, "upon what facts do you rely in support of that allegation?" As a result of Côté J.A.'s reasons in Can-Air Services Ltd. v. British Aviation Insurance Company Limited, ${ }^{3}$ a change in approach is required.

Côté J.A. thought a question in such form was improper, as it went beyond an inquiry limited to factual matters. In responding to the question, a witness

1. Partners of Macleod Dixon, Barristers and Solicitors, Calgary. The authors wish to thank D.C. Purcell and R.A. Deyholos for their extensive assistance and A.R. Robertson for his helpful comments.

2. Edmonton: Juriliber, 1989.

3. [1989], 1 W.W.R. 750 (Alta. C.A.). 
would be required to select from all facts within his knowledge only those upon which he relied. The court's concerns were as follows: ${ }^{4}$

Because the question demands a selection, it demands a product of the witness's planning. How he is to select is unclear. He may have to decide what evidence is then available or is legally admissible. The question really asks how his lawyer will prove the plea. That may well be based on trial strategy.

It was noted that "compendious questions of fact" are not in themselves objectionable. The approach suggested by the Court of Appeal was as follows: ${ }^{5}$

\begin{abstract}
An examining lawyer could properly say, "Paragraph 4(b) of your Statement of Claim alleges that the driver was impaired by alcohol at the time of the collision. Tell me all the facts about that impairment which you know or must properly inform yourself of." There both the pleading and the question are factual, so the question is proper. If the questioner instead asks "on what facts do you rely for paragraph 4(b)?"', the witness's lawyer may properly object. Then the questioner must decide whether he wants the opposing party's strategy or evidence or law (which he cannot get), or whether he simply wants facts (which he can).
\end{abstract}

The form of question suggested by the Court of Appeal will still require considerable caution on the part of the witness and his counsel, because of a number of potential difficulties. The question is broad enough to perhaps suggest to some witnesses that they should disclose privileged information. Furthermore, depending upon the allegation in question, the witness may be compelled to make determinations of relevancy. For example, if an allegation relates to impaired driving by the opposite party, and the witness being examined has knowledge of prior impaired driving by that party, he would need to determine whether such "similar fact" evidence was relevant.

These are not, however, substantial difficulties. It would seem appropriate for the witness's counsel to become involved when the nature of the allegation and the question are so broad as to raise such difficulties. In the course of most examinations for discovery, such concerns are easily and practically resolved by both counsel.

A number of issues relating to relevance and opinion were reviewed in Opron Construction Co. Ltd. v. The Queen in Right of Alberta. ${ }^{6}$ Dea J. considered a situation where three individual employees as well as the selected officer of the defendant refused to answer certain questions. The court confirmed earlier Alberta decisions in the area of relevance and privilege of documents. The reasons addressing questions of opinion and the duty of an officer to inform himself are of particular interest.

Counsel frequently disagree on the propriety of witnesses testifying as to their opinion at discovery. Dea J., quoting from earlier Court of Appeal decisions, stated that questions eliciting opinion could be asked where the witness's professional or technical competence and conduct were clearly in issue. It is reasonably well understood that this allows questions of opinion to be asked of professional defendants being sued in their personal capacity, such as medical doctors or lawyers, who are defending a claim alleging negligence.

4. Ibid. at 752 .

5. Ibid. at 756. That questions of law are not permitted at examinations for discovery was again confirmed in Leeds v. Province of Alberta (Minister of the Environment) (1989), 68 Alta. L.R. (2d) 322 (C.A.).

6. (1988), 59 Alta. L.R. (2d) 214 (Q.B.). 
What often gives rise to disagreement is whether the discovery officer of a corporation, who has expertise in the areas at issue, may be required to give his opinion. He may not have been personally involved in the incidents giving rise to the action and, it will usually be said, a corporation cannot hold an opinion and thus the officer through whom it speaks should not express opinions on its behalf.

Dea J. clarified this area with the assistance of a comprehensive review of the leading authorities, such as Drake v. Overland, ${ }^{7}$ Czuy v. Mitchell, ${ }^{8}$ and Quality Invt. Ltd. v. Curtis Engineering \& Testing Ltd. ${ }^{9}$ It was concluded that questions of opinion are properly put to an officer where he has held an office with the party and his conduct and activities disclose that his conduct as an expert is at issue in the lawsuit. In dealing with the concern that the corporation may then be saddled with an opinion expressed by an officer which it does not accept, Dea J. indicated that the party's officer could be re-examined under r.207 of the Alberta Rules of Court (to confirm whether the opinion expressed was accepted by the corporation), and this answer could be read in at trial as being "connected" with the earlier questions about the opinion, pursuant to r.214(4).

On appeal ${ }^{10}$, Côté J.A. expressed approval of Dea J.'s reasoning on this point, and added some additional comments. He confirmed that the officer of a corporate party may be asked questions of opinion if he has the relevant expertise and was personally involved in the matters at issue in the lawsuit. It seems to be suggested that in answering such questions the witness is responding not as an officer but as an employee. The effect of such evidence on the corporate party was addressed as follows:"

\footnotetext{
In the first place, when the officer gives his opinion on discovery, he or his counsel may make it clear that it is just his personal view. If the corporation has not adopted it (or rejects it), either can say so. I will not elaborate on what words or devices they might use. As the chambers judge points out, the corporation may use Rule 207 on re-examining the officer, and Rule 214(4) on reading in connected answers at trial.
}

It is unclear whether the corporate party bears the onus of rejecting opinion evidence which it does not accept, or whether the examining party bears the onus of establishing that the opinion has been adopted.

In summary, questions of opinion are legitimate in an examination for discovery where the witness is personally named as a party and his conduct as an expert is at issue in the lawsuit, or where the witness is an officer of a corporation, whose personal conduct on behalf of a corporation is relevant to the issues in the lawsuit. Questions as to the opinion of an officer whose personal conduct was not involved in the matters at issue in the lawsuit need not be answered.

The extent of an officer's duty to inform himself, particularly in the context of providing undertakings, was considered in Ed Miller Sales \& Rentals Ltd.

7. [1980] 2 W.W.R. 193 (Alta. C.A.).

8. [1976] 6 W.W.R. 676 (Alta. C.A.).

9. (1985), 44 Alta. L.R. (2d) 108 (C.A.).

10. (1989), 100 A.R. 58 (C.A.).

11. Ibid. at 63 . 
v. Caterpillar Tractor $\mathrm{Co}^{12}$ The plaintiff applied to compel the officer of the defendant to make inquiries of authorized dealers of its products; the defendant sought to compel the plaintiff's officer to inquire of purchasers with whom it contracted to obtain various equipment which it required.

Wachowich $\mathrm{J}$. began by noting "it is clear that a party being examined is bound to inform himself as to matters in question within the knowledge of servants or agents. "13 It then fell to be determined whether the authorized dealers, on the one hand, and the purchasers, on the other, were "agents" for purposes of discovery procedure. In considering what was required to establish an agency in this context, Wachowich J. relied on Canadian Utilities Ltd. v. Mannix Ltd. ${ }^{14}$ While the factors considered were not clearly set forth, it is evident that Wachowich $\mathrm{J}$. was considering the degree of independence between the parties to the lawsuit and their alleged agents. In both cases, he concluded that the relationships were those of independent contractors, and the inquiries were therefore not required.

Finally, it is of interest to note Brennan J.'s procedural ruling during trial in Nova, an Alberta Corporation v. Guelph Engineering Company's. At issue was whether the evidence of various employees and ex-employees of the plaintiff corporation could be read in as part of the defendants' trial evidence. The "blanket" admission by counsel to the plaintiff that the discovery evidence of the employees constituted the officer's information was the basis for Brennan J.'s ruling.

Having ruled on admissibility, Brennan J. considered what effect should be given to the employees' evidence after it was read into the trial record. He concluded that such evidence was "simply evidence of the facts contained therein"'16; the corporation was bound by the admission that the evidence was its information, but was entitled to dispute the truth of the information by calling other evidence.

In the result, one need only obtain the officer's confirmation that the employee's evidence is information relating to the matters at issue in the lawsuit, as a basis for reading in the employee's answers at trial. It is not necessary to have the officer "accept" or "adopt" the employee's evidence as truthful (which was often thought necessary before this decision) as a basis for reading in the answers at trial. Of course, it is preferable to have an officer accept the employee's evidence as truthful, as this would preclude the corporation from calling contrary evidence, but the officer is not required to "accept" or "reject" the employee's evidence.

It is interesting to compare the Ontario Court of Appeal's approach to a similar issue in Clairborne Industries Ltd. v. National Bank of Canada ${ }^{17}$. Carthy J.A. did not refer to Brennan J.'s trial ruling in Nova, An Alberta Corporation

12. (1988), 57 Alta. L.R. (2d) 187 (Q.B.).

13. lbid. at 189.

14. (1959), 29 W.W.R. 289 (Alta. C.A.).

15. (1986), 57 Alta. L.R. (2d) 15 (Q.B.).

16. Ibid. at 22 .

17. (1989), 59 D.L.R. (4th) 533 (Ont. C.A.). 
v. Guelph Engineering Company, but did consider earlier decisions from Saskatchewan and Alberta.

The Clairborne case involved complex allegations of conspiracy and breach of trust. A bank employee had given hearsay evidence at examinations for discovery concerning certain transactions which tended to associate the bank with the creation of a cheque. It seems (although this is not entirely clear) that the employee was the bank's officer at discovery. He had not provided any comment on his hearsay information.

Carthy J.A. ruled that it should therefore be considered as adopted by the bank. He considered "that it should be incumbent upon the party answering questions to identify any reservations as to accuracy or any reason that the answers are not being adopted, including answers based on information received from persons who are not in the employ of the party. "18 The witness should, in Carthy J.A.'s view, qualify the information during his evidence or deal with the matter by correspondence following examination. Dea J.'s suggestion in Opron Construction Co. Ltd. v. The Queen in Right of Alberta of a re-examination under r.207 might be appropriate here as well. The point emphasized in the Clairborne decision is that the onus to identify adoption of statements made on discovery should rest with the party making them.

It should, however, be noted that in Alberta, based on the Nova decision, information of an officer is not taken to be adopted unless done so expressly. In other words, in Alberta the onus has been on the party conducting the examination to establish the adoptions; in Ontario, the onus rests on the witness. This may now be called into question by Côté J.A.'s comments on the effect of an officer's opinion on the corporate party in the Opron decision. ${ }^{19}$

\section{DISCOVERY: DOCUMENTS}

In Ed Miller Sales \& Rentals Ltd. v. Caterpillar Tractor Co.,${ }^{20}$ the court considered a claim of privilege for working papers relating to an accounting report prepared years before the civil action, in respect of an investigation under the Combines Investigation Act. ${ }^{21}$ Privilege had been claimed on the basis of contemplation of litigation, and it thus fell to be considered whether the "dominant purpose" test in Nova, An Alberta Corporation v. Guelph Engineering Company, ${ }^{22}$ was satisfied.

Laycraft C.J.A., for the court, concluded that the investigation under the Combines Investigation Act was, in the context of a privilege claim, litigation. It is of particular interest to note that the "litigation privilege" is not restricted to the litigation in which the motion is later brought, and may arise at the investigation stage. ${ }^{23} \mathrm{He}$ emphasized that "the bulwark of defence one seeks

18. Ibid. at $\mathbf{5 4 5 .}$

19. Supra, note 10.

20. (1988) 90 A.R. 323 (C.A.).

21. Now the Competition Act, S.C. 1986 c. C-26.

22. [1984] 3 W.W.R. 314 (Alta. C.A.).

23. The distinction between litigation privilege, solicitor and client privilege and contractual or "without prejudice" privilege was emphasized and commented on by Côté J.A. in Opron Construction Co. Lid. v. The Queen in Right of Alberta. Supra, note 10. 
to erect" will be hollow if privilege cannot attach at the very earliest stages of the proceedings. ${ }^{24}$

It was also argued that privilege over the working papers had been waived, when the report was presented to the Director of Investigation and Research under the Combines Investigation Act. The court dismissed this argument, on the basis that the director's investigation was conducted in private, and that handing a privileged document to a party to the litigation (such as in an attempt to settle) does not show an intention vis à vis other parties or in related litigation to waive the privilege. The report had also been produced by one party in the litigation; Laycraft C.J.A. likewise considered that this did not constitute a waiver on the part of another party, as it could not interfere with a co-defendant's production.

Another issue on the application concerned the producibility of depositions of American witnesses made in a related lawsuit. The proceedings in the American action were subject to a confidentiality order of the American courts, granted with consent of the parties. Laycraft C.J.A. noted that the consent basis of the order made it probable that the restrictions could be modified, and expressed the view that the production of discovery transcripts is not a question of privilege, but rather a question of whether they are used for an improper purpose. The transcripts were ordered to be produced.

The same parties were before the Court of Queen's Bench ${ }^{25}$ on another application by the defendant seeking production of various statements in the hands of the plaintiff. The first issue was whether statements taken by the plaintiff of certain of its employees who were formerly employed by the defendant should be produced to the defendant. Wachowich J. referred to the decision in Strass v. Goldsack, ${ }^{26}$ in which it was ruled that a statement given by a party opposite in interest must always be produced. Wachowich $\mathrm{J}$. noted that he had in 85th Ave. Dev. Co. v. INS. ${ }^{27}$ extended the exception to require production of statements taken from officers, representatives or servants of a corporate party adverse in interest.

In the matter at bar, Wachowich J. ordered that "the statements in question should be produced so far as they relate to events which occurred while the person was employed by [the defendant] ' ${ }^{28}$. Privilege would attach to those parts of the statements dealing with events after the employees left the defendant's employ.

The second group of statements at issue were those taken from authorized dealers of the defendant by the plaintiff. In this instance, Wachowich J. concluded that the statements were gathered in furtherance of the plaintiff's case, and were privileged.

Questions of privilege arose again in S.E. Johnson Management Ltd. v. Pigott Construction Limited, ${ }^{29}$ where most of the disputes concerned produc-

24. Supra, note 20 at 327.

25. Supra, note 12.

26. [1975], 6 W.W.R. 155 (Alta. C.A.).

27. (1986), 44 Alta. L.R. (2d) 142 (Q.B.).

28. Supra, note 12 at 191.

29. (1988) 57 Alta. L.R. (2d) 394 (Q.B.). 
tion of communications between counsel. There were a number of lawsuits involved; in two actions, the plaintiff was adverse in interest to the defendant hospital board. In an earlier proceeding, the hospital board had produced a "without prejudice" telex relating to settlement discussions, and the plaintiff's counsel had examined the hospital board's officer on the telex. It was therefore held that the plaintiff had waived privilege over the document, and in these proceedings, another party adverse in interest to the plaintiff, Pigott Construction Limited, was granted the right to inquire into all discussions between counsel prior to the writing and delivery of the telex. (The "contractual privilege" of without prejudice communications was not impeached for communications subsequent to the telex.)

Pigott Construction Limited further sought production of all communications between counsel for the plaintiff and other parties to the lawsuits, including excerpts from memoranda on counsel's file. Mason J. ordered that Pigott Construction Limited was entitled to production of these materials and to examine thereon, subject to two qualifications, namely that only communications (oral and written) could be subject to discovery, and that "without prejudice" or contractually privileged communications remained privileged. While it was proper to inquire into statements made by counsel of the parties, this could be done through an officer informing himself, rather than by an examination of counsel.

Mason J. also held that communications between counsel for parties not adverse in interest remained privileged, as they arose for the dominant purpose of conduct of the litigation. However, he also indicated that "only the facts that are or may be relevant to the determination of the facts in issue, reflected in the notes of the conversations, need be disclosed "30. The distinction is not entirely clear in the judgment, but it appears that Mason J. was simply noting the principle that while communications might be privileged, facts referred to in the communications are not privileged simply because they form part of the communication. The facts themselves remain the subject of proper inquiries.

In the context of discussions over privilege, it is of interest to note a recent decision from another jurisdiction, Hodgkinson v. Simms. ${ }^{31}$ McEachern C.J.B.C. (with Taggart J.A. concurring, and Craig J.A. dissenting) considered the familiar question of whether documents which would otherwise be producible might become privileged if gathered in the course of investigations by a party's solicitors. The point frequently arises where one party has conducted an extensive investigation, which might include an entire collection of documents establishing a chain of title to various lands, or perhaps copies of the contents of a fire marshall's or police officer's report. There is understandably a reluctance to provide material of this nature to the opposite party, both because it acquires "cheaply" the fruits of what might have been an expensive investigation; and it could show the approach and tactics of the party which conducted the investigation.

In Hodgkinson, a case involving the plaintiff's investment in various projects on the advice of defendant accountants, the plaintiff objected to producing a number of photocopied documents which it described as "documents obtained 
by the Solicitor for the Plaintiff after this litigation arose for the dominant purpose of preparing for this litigation and forming a part of the Plaintiff Solicitor brief." 32 After reviewing a number of British and Canadian authorities, McEachem C.J.B.C. held as follows: ${ }^{33}$

It is my conclusion that the law has always been, and, in my view, should continue to be, that in circumstances such as these, where a lawyer exercising legal knowledge, skill, judgment and industry has assembled a collection of relevant copied documents for his brief for the purpose of advising on or conducting anticipated or pending litigation he is entitled, indeed required, unless the client consents, to claim privilege for such collection and to refuse production.

This is an interesting point which will, no doubt, require further consideration in Alberta. It has, for example, been suggested that "a collection of documents for which privilege could not be claimed individually will not be considered privileged only because they have been collected by a solicitor". ${ }^{34}$

As a final point in reviewing developments on production of documents, there are recent decisions dealing with documents in the possession of third parties. In Ed Miller Sales \& Rentals Ltd. v. Caterpillar Tractor Co. ${ }^{35}$ the defendants sought to compel a bank, not a party to the action, to produce documents relating to the bank's dealings with the plaintiff. The application was made under r.209(1) of the Alberta Rules of Court, which authorizes production of documents in the possession of third parties. It was established that the bank had been intimately involved in the plaintiff's operations, and there was reason to believe that much of the information sought of the plaintiff was in the bank's possession.

In considering the application, Wachowich J. applied the standard of "probable relevance" which had been applied in Rhoades v. Occidental Life Insurance Company of California ${ }^{36}$ as the test for determining whether a stranger should be compelled to produce documents. He set out the four requirements used by the British Columbia Court of Appeal, and added a fifth condition based on Markowitz v. Toronto Transit Commission ${ }^{37}$ The five criteria applied by Wachowich J. were the following: ${ }^{38}$

1. The rule should not be used as a fishing expedition to discover whether or not a person is in possession of a document.

2. The document need not necessarily be admissible in evidence at trial.

3. The documents of which production is sought must be adequately described, but not necessarily so specifically that they can be picked out from any number of other documents.

4. The third party's objections to production must be considered, but are not determinative.

5. [T]he rule cannot be used as a method of obtaining discovery of a person not a party to the action.

32. Ibid. at 135.

33. Ibid. at 145.

34. Thompson, "Practice Notes on Discovery Rules," (1987), 57 Alta. L.R. (2d) 23.

35. (1988) 63 Alta. L.R. (2d) 189 (Q.B.).

36. [1973] 3 W.W.R. 625 (B.C.C.A.).

37. [1965] 2 O.R. 215 (Ont. H.C.).

38. Supra, n.35 at 191-192. 
On the basis of these criteria, Wachowich J. ordered that certain described material be produced by the bank; it was not required to produce its internal communications and analyses.

\section{COMPROMISE PROCEDURES}

The Court of Appeal's decision in Whittle v. Davies ${ }^{39}$ while now generally well known among members of the bar, is worth reviewing because of the guidance it offers in dealing with offers under the compromise procedures of the Rules of Court.

The defendants had made payment into court under r.166 for one of the plaintiffs, dividing the payment into amounts for general damages and the entire claim for hospital and ambulance services. The plaintiffs were found 25 percent responsible, and therefore recovered 75 percent of the damages.

In comparing the payment into court with the judgment, the judgment exclusive of prejudgment interest was less than the payment in, but when prejudgment interest was included, the amount recovered exceeded the payment into court. Even without considering prejudgment interest, the award for general damages exceeded the allocation to general damages contained in the payment into court. The trial judge concluded that, notwithstanding a payment into court, costs remain in the discretion of the court and costs were awarded to the plaintiff.

Stevenson J.A., for the court, began by disagreeing with the trial judge's view that the court retained its general discretion over costs when the provisions of r.174 (dealing with the effect of payments into court, offers of judgment and offers to settle) became applicable. He stated as follows: ${ }^{40}$

The judge ought to have considered whether R.174 applies. If it applies, costs are not "in the discretion of the court," but are awarded to the defendants "unless for special reason."

In the case before him, however, Stevenson J.A. found there to be "special reason" in that the defendants had made payment into court by dividing the elements of the offer; offering too much for the hospitals claims and too little for the general damages claim. It was noted that this placed the plaintiff in an awkward position in negotiating with the Hospitals Division with respect to its part of the claim. It was held that the defendants could not have "the best of both worlds" by submitting an offer breaking down the component parts of the claim, and then seeking to rely on the global amount of the offer in speaking to costs after trial.

Stevenson J.A. proceeded to offer guidance on the impact of prejudgment interest on payments into court. After reviewing a number of English and Canadian authorities, he expressed the view that payments into court must value, as of the date of payment in, the principal amount of the claim plus prejudgment interest. While the reasons did not address offers of judgment (r.169) or offers to settle (r.170), the same principles seem to apply. It is, therefore, advisable for parties making formal offers to either add a specific amount for prejudgment interest, or specify that prejudgment interest will be added to the offer if accepted. 
Another decision offering guidance on the proper structuring of formal offers is F.J. McDaniel Limited v. F \& F Holdings Ltd. ${ }^{41}$ The plaintiff had initially made an offer to settle which involved a payment by the defendant on the plaintiff's claim, and a discontinuance of the defendant's counterclaim. The result at trial was a division of liability; the defendant made some recovery on its counterclaim, but the plaintiff's net recovery exceeded the amount in its offer to settle. (A second offer to settle by the plaintiff, made on the morning of trial, dealt both with the claim and counterclaim specifically, but the plaintiff preferred to rely on its earlier offer in order to recover additional disbursements.)

In considering the effects of the plaintiff's offer under r.174(2), Veit J. ruled that " "recovery' is the test by which the situation of the parties is governed under r.174" ${ }^{42}$. Accordingly, while the defendant had been partially successful in its counterclaim, in terms of a net recovery the plaintiff had been adjudged entitled to more than the amount disclosed in its offer to settle, and was thus entitled to double costs.

There is, perhaps, room for debate on whether Veit J.'s approach is consistent with that of the Court of Appeal in Whittle v. Davies. ${ }^{43}$ The offer which the plaintiff relied upon in $M c D a n i e l$ required a discontinuance of the counterclaim. Use of the "net recovery" rule ignores the fact that one of the defendants had been successful as a plaintiff by counterclaim. It is also common knowledge that, apart from the main parties themselves, different insurance considerations may apply as between the conduct of the defence and prosecution of the counterclaim.

One of the plaintiff's arguments in McDaniel was that "the solicitor for the defendants was obligated to negotiate those adjustments as between his clients as would make the offer acceptable between them'. It would appear that this type of difficulty falls squarely within the ambit of Stevenson J.A.'s suggestion of what might constitute "special reason" within the meaning of r.174.

It is, finally, perhaps worth noting that there have been difficulties presented by differences between r.169 and 170, as to when offers are available for acceptance. Until recently, r. 169 required that a defendant's offer of judgment be available for acceptance at least 45 days from service, while r. 170 expressly limited a defendant's right to accept a plaintiffs' offer to settle to "anytime before the commencement of trial." This led to an instance where the plaintiffs attempted to accept a defendant's offer of judgment after close of the plaintiffs' case, although the defendant had orally revoked its offer (Brown v. Shortreed's Estate), ${ }^{44}$ and a case where the plaintiff applied for judgment pursuant to the defendant's offer of judgment after pronouncement of judgment following trial, but before entry of formal judgment (Couillard v. Waschulewski Estate $)^{45}$. In the former case, the Court of Appeal ordered that the offer was still available for acceptance, as the offer could not be revoked before 45 days,

41. (1987), 92 A.R. 280 (Q.B.).

42. Ibid. at 282; Veit J. referring to decision of Dea J. in Spruce Grove v. Donaldson, unreponted, September 12, 1986.

43. Supra, n.39.

44. (1988), 86 A.R. 265 (C.A.).

45. (1988), 61 A.R. (2d) 226 (Q.B.). 
and the rules do not contemplate oral withdrawal of an offer; in the latter case, it was held that a judgment took effect from pronouncement, rather than entry, and the application for judgment pursuant to the offer was therefore dismissed.

The anomalous difference in the rules has now been clarified (Alberta Regulation 150/89), effective June 22, 1989, so that offers of judgment by the defendant under r.169 can now only be accepted at any time before the commencement of trial, as has always been the case with offers to settle by the plaintiff under r.170.

The Court of Appeal had earlier considered the situation where a plaintiff is awarded double costs pursuant to r.174 (having received a judgment larger than the offer to settle) and the defendant thereafter appeals unsuccessfully. In Davis v. Caproco Corrosion Prevention Ltd. ${ }^{46}$ Kerans J.A. dismissed the plaintiff's application for double costs for the appeal, because the offer to settle was not renewed after judgment. A party wishing to recover double costs pursuant to r.174 for the appeal should therefore serve a new offer during the appeal process.

\section{ISSUANCE AND AMENDMENT OF PLEADINGS AFTER TIME DEADLINES}

The Court of Appeal has recently, on two occasions, considered applications to amend pleadings after expiry of a limitation period. In the first decision, the question was whether a new party could be substituted, and in the second decision, whether a new cause of action could be added.

Frank v. King Estate ${ }^{47}$ involved two separate appeals, heard together by a five-member panel. In one of the actions, the plaintiff Laurien, driving her own vehicle, had been injured in a motor vehicle accident, and brought an action against the deceased driver and owner of the other motor vehicle. The plaintiff had obtained an order appointing the Public Trustee as administrator ad litem of the estate, and the Public Trustee was named as defendant; in fact, an administrator of the estate had already been appointed by the Surrogate Court.

The defendant successfully moved to strike out the statement of claim as against the Public Trustee on the ground that there was no jurisdiction in the court under the Survival of Actions Act ${ }^{48}$ and the Administration of Estates $A c t^{49}$ to appoint the Public Trustee as administrator ad litem when the deceased person was represented by an administrator duly appointed.

In the second case, the plaintiff Frank had been a passenger in a motor vehicle involved in a collision. The driver of the vehicle died in the collision, and the plaintiff named as defendani "the estate of Raymond King," without naming its personal representative. King was a native Indian, and federal regulations automatically made the Superintendent of Indian and Northern Affairs administrator of the estate. The Department of Indian and Northern Affairs was sub-

46. (1987), 50 Alta. L.R. (2d) 23 (C.A.); see also Rahmath v. Louisiana Land and Exploration Co. (1989), 65 D.L.R. (4th) 150 (Alta. C.A.).

47. (1987), 88 A.R. 241 (C.A.).

48. R.S.A. 1980 , c. S-30.

49. R.S.A. 1980 , c. A-1, as am. 
stituted as a defendant by consent order, obtained without the knowledge of King's insurers, who later moved to set aside the consent order and strike out the statement of claim.

In dealing with the Laurien action, Stevenson J.A., for the court, did not accept the argument that the order appointing the Public Trustee as administrator ad litem was void $a b$ initio, but rather found it to be valid until set aside; it "was irregular, at most voidable".${ }^{50} \mathrm{He}$ nevertheless agreed that the order appointing the Public Trustee should be set aside, because the Survival of Actions Act authorized appointment of an administrator ad litem only in the absence of a personal representative, and the Administration of Estates Act precluded any other representative from acting after the issue of a grant of administration. Having concluded that the order was invalid, the Court of Appeal considered whether a substitution of the personal representative as defendant should be allowed concurrently.

The Court of Appeal distinguished its earlier decision in Buteau v. Public Trustee for Alberta,${ }^{51}$ where it was held that an action commenced against 'the estate of' a named person was a nullity. Stevenson J.A. thought the difference was that in Buteau there was no validly appointed administrator ad litem at any time prior to expiry of the limitation period. He went on, however, to reinforce the proposition that an action against a deceased without naming a personal representative would not allow for substitution: ${ }^{52}$

The weight of that authority would preclude substitution of personal representative where the action was brought against a "deceased", when there was no personal representative in existence.

Presumably, Stevenson J.A. meant that an action against an estate would be a nullity; section 61 of the Limitation of Actions $A c t^{53}$ allows an amendment after a limitation period where an individual, who has died unbeknownst to the plaintiff, has been named as a defendant as though he were alive.

Stevenson J.A. also emphasized that, in general, substitutions will not be allowed after expiry of a limitation period: ${ }^{34}$

Moreover, where substitutions are sought after a limitation period has expired parties will not, as a general nule, be added where the effect is to deprive them of an applicable limitation period.

In dealing with the matter at bar, it was noted in the first place that there was no suggestion of prejudice. Stevenson J.A. then considered it important that there was a personal representative appointed and named prior to expiry of the limitation period, and while the appointment was irregular, there were two existing parties, one of whom could be substituted for the other. There was also the unusual circumstance that the personal representative of the deceased had also been named in the statement of claim in her personal capacity. In summary: 55

It is not a case of adding something to nothing: it is a case of substituting the proper party

for one irregularly appointed, but appointed nonetheless.

50. Supra, note 47 at 245.

51. [1972], 2 W.W.R. 177 (Alta. C.A.).

52. Supra, note 47 at 246.

53. R.S.A. 1980 , c. L-15, as am.

54. Supra, note 47 at 246.

55. Ibid. at 247. 
In the proceedings commenced by Frank, there was again no suggestion of prejudice. The court noted that the named defendant, the estate of the deceased, did not constitute an entity which could be sued. The court also took into consideration that at the commencement of the action, there was a personal representative of the deceased, the Department of Indian and Northern Affairs. The court reconsidered its reasoning in Buteau, by finding that actions against the estate of a deceased person should no longer be characterized as nullities. In the words of Stevenson J.A.: ${ }^{56}$
It is, in my view, in keeping with current legislation and the principle that ought to be applied, that the court, in deciding whether to add or substitute a party to an action, ought not con- cem itself with whether the action is a "nullity", but whether the amendment results in prejudice, bearing in mind express limitation periods and the principles behind them. Has the proper defendant, the personal representative, been misled or substantially prejudiced by the amendment?

The court approved the approach recommended in an article by Professor G.D. Watson. ${ }^{57}$

The court expressed an inclination to characterize error as an irregularity rather than a nullity. Stevenson J.A. criticized the concept of the incurable nullity: ${ }^{58}$

Error, however, must not be compounded into injustice and the almost invariable result of characterizing proceedings as a nullity with automatic consequences tends to that end, a view forcibly expressed by Professor Watson who calls the cases on nullity "a blot" on justice.

Stevenson J.A. had the opportunity to consider similar issues in Corrigan v. Fanta and Wetaskiwin Industrial Machine and Welding Ltd. ${ }^{59}$, where the statement of claim named the owner and driver of a motor vehicle, but did not plead that the driver was operating the vehicle with consent of the owner. The chambers judge concluded that the facts necessary to establish a cause of action against the owner had therefore not been pleaded, and the statement of claim as against the owner was struck out.

On appeal, Stevenson J.A. assumed the absence of a cause of action (without deciding the point), and then found that there were sufficient "special circumstances" to allow an amendment after the limitation period. The plaintiff's counsel had proposed the amendment before the expiry of the limitation period, and the defendants were therefore aware of the proposed claim.

Stevenson J.A. also considered the old rule in Weldon v. Neal ${ }^{60}$ which is said to bar an amendment sought after the limitation period has expired. He suggested that, if it were necessary, consideration should be given to whether Weldon v. Neal was still good law in Alberta, or "whether it should be replaced by the functional approach which this court applied in Frank v. King Estate..."61

There are, however, still a number of requirements which must be established to obtain an amendment outside the limitation period. In Brochner v.

56. Ibid. at 249.

57. "The Amendment of Proceedings After the Expiry of Limitation Periods" (1975) 53 Can. Bar Rev. 237 at 266-67.

58. Supra, note 47 at 250.

59. (1989), 96 A.R. 293 (C.A.).

60. (1887), 19 Q.B.D. 394.

61. Supra, note 59 at 294. 
MacDonald ${ }^{62}$ Stevenson J.A. refused an amendment where the plaintiff had named a "John Doe" as a defendant. The "misnomer rule" was not satisfied, as an allegation of negligence had not been made against John Doe which would provide the basis of a substitution. Furthermore, with regard to adding a defendant outside the limitation period, the plaintiff had not provided "timely notice" and therefore the tests for adding a defendant were not met.

The new approach illustrated in Frank v. King Estate has been applied in a number of circumstances. In Robinson Engineering Company Ltd. v. Wasabi Resources Ltd. ${ }^{63}$ Hutchinson J. allowed the plaintiffs to substitute the names of trustees, when the statement of claim had initially only named the trusts (these facts being analogous to the naming of an estate rather than a personal representative). In Dumaine v. Kerry and Canada Post Corp.,${ }^{64}$ a case on facts very similar to Corrigan v. Fanta, Murray J. concluded that an amendment to plead the necessary facts to establish vicarious liability on the part of Canada Post for the actions of the driver of one of its mail trucks should be allowed. (This decision was reached without the benefit of the Corrigan v. Fanta case.)

On a related front, the Court of Appeal has also reviewed the requirements for allowing an extension for issuing and serving a third party notice. Rule 66 provides that a third party notice should be filed and served within six months of issuance of the defendant's statement of defence. In E.S.M. Transport Ltd. v. Western Mack Truck (Edmonton) Ltd. ${ }^{65}$ the court dealt with a situation where an order had been made by a master extending the time for filing and serving a third party notice. An appeal from that order was dismissed by a judge in chambers. On further appeal, the Court of Appeal set aside the order extending the time for bringing these third party proceedings. It was held that the defendant's delay in issuing third party proceedings was inexcusable in that it knew from the time that it filed its pleadings that it had a potential third party claim but chose not to then advance it, to avoid offending the third party, Mack Canada Inc.

The court found substantial prejudice to either the plaintiff or the third party because the late issuance of the third party notice would have required an adjournment of the trial date. The defendant on the other hand, was not "irredeemably prejudiced" in that it could still claim indemnity against the proposed third party in a separate action.

The reasoning of the Court of Appeal in E.S.M. Transport Ltd. was followed recently in Labell v. $R$. Jo Enterprises Ltd. et al. , ${ }^{66}$ where the two-year delay in filing and serving a third party notice was found to be inordinate and inexcusable, and prejudice to the plaintiff's right to an early trial outweighed the defendant's interest in having the entire matter dealt with in one proceeding. Accordingly the application to extend the time for filing and serving the third party notice was dismissed.

62. (1989), 68 Alta. L.R. (2d) 191 (C.A.).

63. (1988), 93 A.R. 32 (Q.B.).

64. (1988), 87 A.R. 70 (Q.B.).

65. (1988), 59 Alta. L.R. (2d) 115 (C.A.).

66. (1989), 94 A.R. 62 (Q.B.). 
These cases illustrate the difficulties which may be encountered in seeking to issue a third party notice outside the usual six-month period. Procedure therefore dictates that counsel assess their case at an early date following filing of a statement of defence.

\section{SECURITY FOR COSTS}

Until recently, r.593 which allows for the posting of security for costs, had been a common tool used by defendants in responding to claims brought by plaintiffs residing out of Alberta in cases where the defendant considered it had a good defence on the merits. The rule had long been considered an effective means of compelling many plaintiffs to consider the merits of their claims at an early stage. Recently, however, the validity of the security for costs rule as it applied to non-resident plaintiffs was called into question.

There were two decisions of the Court of Queen's Bench which reached different conclusions. The first was Kask v. Shimizu ${ }^{67}$, in which D.C. McDonald J. found that the rule contravened subsection 15(1) (equality rights) of the Canadian Charter of Rights and Freedoms, 1982, and was not a reasonable limit within the meaning of section 1 of the Charter. In obiter dictum, D.C. McDonald J. also expressed the view that the rule offended subsection 6(2)(a) of the Charter (mobility rights).

In contrast, the rule was upheld in Singh v. Dura.$^{68}$ Berger J. found that while the rule distinguished between resident and non-resident plaintiffs, it was not discriminatory, and further did not offend mobility rights. This decision was followed by Prowse J. in Aukema v. Bernier Kitchen Cabinets Inc. ${ }^{69}$

With these conflicting decisions, leaving parties uncertain as to the validity of the rule, the Court of Appeal fortunately resolved the point clearly in its recent decision in Singh v. Dura. ${ }^{70}$ The plaintiff was an Ontario resident who had sustained a leg injury. The defendant had obtained an order requiring $\$ 1,300.00$ to be posted as security for costs. The appeal from this decision was dismissed, with Côté J.A. holding that the rule did not violate the equality or mobility provisions of the Charter and, in any event, could be justified under section 1 of the Charter as a reasonable limit prescribed by law.

In a comprehensive review of the law and practice surrounding security for costs rules, Côté J.A. identified the special difficulties a defendant has in executing on a costs judgment against a non-resident plaintiff. He further stated that security for costs will not be automatically granted against a non-resident plaintiff, but rather, each defendant's application must survive a "10-step sorting process." 71 For example, it must be established that there appears to be a good defence, and the court may exercise its discretion in favour of a "poor plaintiff" in some instances. Furthermore, Côté J.A. listed a number

67. (1986), 69 A.R. 343 (Q.B.).

68. (1987), 80 A.R. 347 (Q.B.).

69. (1987), 80 A.R. 354 (Q.B.); see also Nissho v. Bank of British Columbia (1987), 39 D.L.R. (4th) 453 (Aita. Q.B.).

70. (1988), 86 A.R. 268 (C.A.).

71. Ibid. at 273. 
of examples where plaintiffs residing in Alberta may be required to give security for costs.

Côté J.A. then addressed the application of subsections 15(1) and 6(2) of the Charter. With regard to subsection 15(1), it was held as follows: ${ }^{72}$

Here the criterion, non residence of a plaintiff, is both relevant and sufficient to justify security for costs . . . The large number of exceptions and qualifications to security for costs against non-residents . . . and the large number of grounds for security against residents . . . show that their legal positions are not clearly different.

In dismissing the plaintiff's arguments on subsection 6(2) of the Charter, the Court stated as follows: ${ }^{73}$

Rule 593 does not govem where one may live or work; it is about when one should make assets available to sue [citing authority]. . . . Someone who works in Alberta would be resident in Alberta, maybe even for some time after he leaves that work. It is very difficult to conceive how someone could pursue the 'gaining of a livelihood' in Alberta with neither residence nor assets in Alberta.

Finally, it was held that even if the rule violated section 15 of the Charter, it was saved by section 1. In the words of Côté J.A., "the means used are rational, proportional, and individually tailored to do as little harm as possible in each case." 74

\section{INDEPENDENT MEDICAL EXAMINATION}

It is common in personal injury lawsuits for the defendant to use r.217 to compel the plaintiff to attend before a medical practitioner for what has come to be known as an "independent medical examination". In cases where the plaintiff is alleging psychological problems resulting from the accident, controversy often arises over the defendant's selection of medical professionals to conduct the examination. Specifically, objections are often taken to a psychologist or neuropsychologist conducting the independent medical examination on the basis that he is not, in the words of the rule, a "duly qualified medical practitioner."

This controversy came before the courts in Blackburn v. Kochs Trucking Inc. ${ }^{75}$ The defendant applied for an order requiring the plaintiff, who complained of severe anxiety and depression, to attend before a psychologist for an examination under r.217. One of the stated objectives of the examination was for the psychologist to assess the plaintiff's psychological condition and to express opinions on employability, capacity to care for herself and the cost of care.

The application was dismissed for two reasons. First, D.C. McDonald J. was of the view that the psychologist could form his opinion as to the plaintiff's employability and ability to care for herself from answers given by the plaintiff either at examinations for discovery or trial. Secondly, the court concluded that a psychologist does not fall within the definitions contained in the Medical Profession Act ${ }^{76}$ A person who is not a duly qualified medical prac-

72. lbid. at 278.

73. lbid. at 279.

74. Ibid. at 280.

75. (1988), 58 Alta. L.R. (2d) 358 (Q.B.).

76. R.S.A. 1980 , c. M-12, as am. 
titioner could conduct an examination only where reasonably necessary for a "medical practitioner" to make a diagnosis and prognosis.

The restrictive wording of r.217 and the illustrations of its application in Blackburn leaves a defendant in a difficult position when dealing with a case where psychological injuries are alleged by the plaintiff. Three options present themselves to the defence counsel in this position, none of which are particularly satisfactory:

1. The defence may forego retaining an expert to deal with this aspect of the plaintiff's claim. This of course leaves the plaintiff's evidence on the point effectively unchallenged at trial, which may be a significant detriment.

2. The defence may collect information concerning the plaintiff's condition at discovery and through medical reports obtained from the plaintiff, and submit this information for evaluation to a psychologist (one of the options implicitly suggested by D.C. McDonald J. in his reasons). This allows the defence to choose its own expert, but the trial judge may be less impressed with an expert who has not seen or personally interviewed the plaintiff, than with the plaintiff's treating psychologists and physicians.

3. The defence may wish to take advantage of r.218, which allows the court to appoint an independent expert. Such an order could be made where the defence satisfies the court that an expert (such as a psychologist) is required in the interest of a fair trial. This may be appropriate where psychological effects form a significant part of the plaintiff's claim and is supported by expert evidence on the plaintiff's behalf. This rule (also suggested as an alternative in Blackburn) is of limited value to the defence, however, as the expert will be "independent"; he will be chosen by agreement of both parties or, failing agreement, by the court's nomination.

From the defence perspective, it is apparent that none of the foregoing options adequately compensate for the restrictions in r.217. In view of the increasing prevalence of personal injury actions with psychological aspects forming important parts of the claim, it may be time to re-evaluate the restrictive scope of the examinations permitted under the r.217.

The same issues were considered in Carifelle v. Griep ${ }^{n}$. The defendant had unsuccessfully applied before the master and then a judge of the Court of Queen's Bench for a psychological examination of an infant plaintiff on the eve of trial. The court (the panel was comprised of Lieberman and Côté J.A., and Miller, J., ad hoc, no author of the reasons identified) noted the difficulty "that the examination is to be by a psychologist, not by a physician registered under the Medical Profession Act." The plaintiffs had conceded that under r.217 the court could order an examination by someone who was not a registered medical practitioner if necessary to enable a medical practitioner to examine or evaluate an injured plaintiff. The court acted on that concession, but expressly declined from affirming whether it was the law. 
The defendant had provided an affidavit by a medical practitioner, who deposed to the assistance which a psychological examination would provide to him. The court had some concerns about the sufficiency of the affidavit, but in the unusual circumstances of the case before it, allowed the application and ordered the psychological examination on a number of terms and conditions. 